\title{
PEMBELAJARAN KONTEKSTUAL MELALUI PERMAINAN KELERENG PADA SISWA KELAS III SD UNTUK MENINGKATKAN PEMAHAMAN KONSEP PERKALIAN
}

\author{
Maria Fatima $\mathrm{Mei}^{1}$, Stefania Baptis Seto ${ }^{2}$, Maria Trisna Sero Wondo ${ }^{3}$ \\ ${ }^{1}$ Universitas Flores, Jln. Sam Ratulangi, Ende-Flores-NTT \\ ${ }^{2}$ Universitas Flores, Jln. Sam Ratulangi, Ende-Flores-NTT \\ ${ }^{3}$ Universitas Flores, Jln. Sam Ratulangi, Ende-Flores-NTT \\ Email: imajevan202019@gmail.com
}

\begin{abstract}
The purpose of this study was to describe an increase in the ability to understand mathematical concepts, teaching skills of teachers in managing mathematics learning and student learning activities using contextual learning models through marble games. This type of research is Classroom Action Research (PTK). The subjects of the research were 15-grade students of SDI Tetandara. The data collection techniques used were observation, interview, test, and documentation. The instrument in this study used test questions, observation sheets, and interview sheets. Data analysis in this research is quantitative and qualitative data analysis. The results of this study indicate that (1) the increase in teacher activity from pre-cycle to cycle I am $15.75 \%$, cycle I to cycle II is $17.45 \%$. (2) Student activity has increased from the pre-cycle to cycle I by $27 \%$, and cycle I to cycle II by 26\%. (3) Increased understanding of the multiplication concept of students in the precycle to cycle I amounted to $26.66 \%$ for indicator 1, $20 \%$ for indicator 2, 6.67\% for indicator 3, and $33.34 \%$ for indicator 4 . As for the first cycle to cycle II has increased by $26.67 \%$ for indicator 1, 26.66\% for indicator $2,33.33 \%$ for indicator 3 , and $26.66 \%$ for indicator 4 .
\end{abstract}

Keywords: contextual learning; marbles game; concept understanding

Abstrak
Tujuan penelitian ini adalah untuk mendeskripsikan peningkatan kemampuan pemahaman konsep matematika, keterampilan mengajar guru dalam mengelola pembelajaran matematika dan aktivitas belajar siswa menggunakan model pembelajaran kontekstual melalui permainan kelereng. Jenis Penelitian ini adalah Penelitian Tindakan Kelas (PTK). Subjek penelitian siswa kelas III SDI Tetandara dengan jumlah siswa 15 orang. Teknik pengumpulan data yang digunakan yaitu observasi, wawancara, tes dan dokumentasi. Instrumen pada penelitian ini menggunakan soal tes, lembar observasi, lembar wawancara. Analisis data dalam penelitian ini adalah analisis data kuantitatif dan kualitatif. Hasil penelitian ini menunjukkan bahwa (1) peningkatan aktivitas guru dari pra siklus ke siklus I sebesar 15,75\%, siklus I ke siklus II sebesar 17,45\%. (2) Aktivitas siswa mengalami peningkatan dari pra siklus ke siklus I sebesar 27\%, dan siklus I ke siklus II sebesar 26\%. (3) Peningkatan pemahaman konsep perkalian siswa pada pra siklus ke siklus I sebesar 26,66\% untuk indikator 1 , $20 \%$ untuk indikator 2, 6,67\% untuk indikator 3, dan 33,34\% untuk indikator 4 . Sedangkan untuk siklus I ke siklus II mengalami peningkatan sebesar $26,67 \%$ untuk indikator $1,26,66 \%$ untuk indikator 2, 33,33\% untuk indikator 3, dan 26,66\% untuk indikator 4.

Kata kunci: pembelajaran kontekstual; permainan kelereng; pemahaman konsep

\section{PENDAHULUAN}

Suatu pembelajaran dikatakan baik jika selama proses pembelajaran semua siswa ikut aktif atau berpatisipasi dalam menjawab maupun bertanya. Proses pembelajaran merupakan suatu bentuk 
Pembelajaran Kontekstual Melalui Permainan Kelereng Pada Siswa Kelas III SD

Untuk Meningkatkan Pemahaman Konsep Perkalian

Maria Fatima $\mathrm{Mei}^{1}$, Stefania Baptis Seto $^{2}$, Maria Trisna Sero Wondo

Jupika: Jurnal Pendidikan Matematika, Volume 3. Nomor 2. September 2020. Hal.61-70

interaksi edukatif, yakni interaksi yang bernilai pendidikan yang dengan sadar meletakkan tujuan untuk mengubah tingkah laku dan perbuatan seseorang. Interaksi edukatif harus menggambarkan hubungan aktif dua arah antara guru dan anak didik dengan sejumlah pengetahuan sebagai mediumnya. Dalam interaksi edukatif unsur guru dan anak didik harus aktif, tidak mungkin terjadi proses interaksi edukatif bila hanya satu unsur yang aktif. Aktif dalam arti sikap, mental, dan perbuatan (Djamarah, 2000).

Pembelajaran matematika merupakan pembelajaran yang dianggap sulit oleh siswa (Mei, 2016) karena pembelajaran tersebut lebih banyak menggunakan rumus-rumus yang harus dihafal untuk mengerjakan soal-soal yang diberikan guru. Dalam pembelajaran matematika membutuhkan tingkat pemahaman yang cukup sehingga dengan pemahaman tersebut siswa tidak hanya menghafal tetapi memaknai apa yang telah diajarkan. Pemahaman konsep dalam pembelajaran matematika merupakan salah satu kecakapan atau kemampuan untuk memahami dan menjelaskan suatu situasi atau tindakan suatu kelas atau kategori, yang memiliki sifat-sifat umum yang diketahuinya dalam matematika (Rahayu, 2018). Hal ini sejalan dengan penelitian (Febriani, dkk, 2019) yang menyatakan bahwa kemampuan pemahaman konsep matematika adalah kemampuan siswa dalam menyampaikan atau menguraikan dan menjelaskan dari bahasa, dengan bahasa sendiri serta mampu menerapkan konsep tersebut pada sebuah permasalahan, kemudian dapat mengaitkan antara satu konsep dengan konsep lainnya. Jadi Penguasaan konsep merupakan tingkatan hasil belajar siswa sehingga dapat mendefinisikan atau menjelaskan sebagian atau mendefinisikan bahan pelajaran dengan menggunakan kalimat sendiri.

Menurut Wardhani (2008) pembelajaran matematika di sekolah memiliki tujuan agar siswa mampu 1) memahami konsep matematika, menjelaskan keterkaitan antar konsep dan mengaplikasikan konsep atau algoritma, secara luwes, akurat, efisien, dan tepat dalam pemecahan masalah, 2) menggunakan penalaran pada pola dan sifat, melakukan manipulasi matematika dalam membuat generalisasi, menyusun bukti, atau menjelaskan gagasan dan pernyataan matematika, 3) memecahkan masalah yang meliputi kemampuan memahami masalah, merancang model matematika, meneyelesaikan model, dan menafsirkan solusi yang diperoleh, 4) mengkomunikasikan gagasan dengan simbol, tabel, diagram, atau media lain untuk memperjelas keadaan atau masalah, 5) memiliki sikap menghargai kegunaan matematika dalam kehidupan, yaitu memiliki rasa ingin tahu, perhatian dan minat dalam mempelajari matematika, serta sikap ulet dan percaya diri dalam pemecahan masalah.

Menurut NCTM (2000), untuk mencapai pemahaman yang bermakna maka pembelajaran matematika harus diarahkan pada pengembangan kemampuan koneksi matematik antar berbagai ide, memahami bagaimana ide-ide matematik saling terkait satu sama lain sehingga terbangun pemahaman menyeluruh, dan menggunakan matematik dalam konteks di luar matematika. Hal ini sejalan dengan (Nila, 2008) yang mengatakan bahwa Siswa memahami konsep jika siswa mampu mendefinisikan 
Pembelajaran Kontekstual Melalui Permainan Kelereng Pada Siswa Kelas III SD

Untuk Meningkatkan Pemahaman Konsep Perkalian

Maria Fatima $\mathrm{Mei}^{1}$, Stefania Baptis $\mathrm{Seto}^{2}$, Maria Trisna Sero Wondo ${ }^{3}$

Jupika: Jurnal Pendidikan Matematika, Volume 3. Nomor 2. September 2020. Hal.61-70

konsep, mengidentifikasi dan memberi contoh atau bukan contoh dari konsep, mengembangkan kemampuan koneksi matematik antar berbagai ide, memahami bagaimana ide-ide matematik saling terkait satu sama lain sehingga terbangun pemahaman menyeluruh, dan menggunakan matematik dalam konteks di luar matematika. Oleh karena itu pembelajaran matematika di kelas seharusnya ditekankan pada keterkaitan antara konsep-konsep matematika yang telah dimiliki anak pada kehidupan sehari-hari (Mei dkk., 2020).

Menurut Duffin \& Simpson (2000) pemahaman konsep sebagai kemampuan siswa untuk: (1) menjelaskan konsep, dapat diartikan siswa mampu untuk mengungkapkan kembali apa yang telah dikomunikasikan kepadanya. (2) menggunakan konsep pada berbagai situasi yang berbeda. Sejalan dengan hal di atas (Depdiknas, 2003) mengungkapkan bahwa, pemahaman konsep merupakan salah satu kecakapan atau kemahiran matematika yang diharapkan dapat tercapai dalam belajar matematika yaitu dengan menunjukkan pemahaman konsep matematika yang dipelajarinya, menjelaskan keterkaitan antar konsep dan mengaplikasikan konsep atau algoritma secara luwes, akurat, efisien, dan tepat dalam pemecahan masalah.

Salah satu pokok bahasan yang dianggap sulit dalam matematika adalah perkalian. Hal ini dibuktikan berdasarkan hasil ulangan yang belum mencapai KKM dan hasil wawancara dengan guru mata pelajaran bersama siswa di SDI Tetandara yang mengatakan bahwa perkalian itu sangat sulit. Kesulitan yang dialami dikarenakan kurangnya kemampuan siswa dalam memahami perkalian. Selain itu ada juga faktor lain yang berpengaruh pada hasil belajar siswa, yaitu dalam pembelajaran guru masih menggunakan pendekatan teacing center artinya bahwa guru menjadi sumber segala pengetahuan yang akan diterima dan diketahui oleh siswa. Maka dari itu diperlukan pemahaman atau proses yang cukup lama dalam menanamkan konsep tersebut. Hal tersebut dapat dilakukan dengan menerapkan suatu pendekatan model pengajaran yang menarik dan bermakna bagi siswa sehingga dapat diserap oleh siwa dengan mudah.

Model pembelajaran yang cocok untuk mengaitkan matematika dengan kehidupan sehari-hari adalah pembelajaran kontekstual. Model Pembelajaran CTL (Contextual Teaching and Learning) adalah suatu sistem pengajaran yang cocok dengan otak yang menghasilkan makna dengan menghubungkan muatan akademis dengan konteks dari kehidupan sehari-hari siswa (Jhonson, 2007). Hal ini sejalan dengan penelitian Jumadi (2004) yang mengatakan bahwa Pembelajaran kontekstual merupakan pembelajaran yang mengkaitkan materi pembelajaran dengan konteks dunia nyata yang dihadapi siswa sehari-hari baik dalam lingkungan keluarga, masyarakat, alam sekitar dan dunia kerja, sehingga siswa mampu membuat hubungan antara pengetahuan yang dimilikinya dengan penerapannya dalam kehidupan sehari-hari, dengan melibatkan tujuh komponen utama pembelajaran yakni kontruktivisme (constructivism), bertanya (questioning), menyelidiki (inquiry), masyarakat belajar (learning community), pemodelan (modeling), refleksi (reflection), dan penilaian autentik (authentic assessment). Menurut Nadawidjaya (Kunandar, 2009), dalam pembelajaran kontekstual 
Pembelajaran Kontekstual Melalui Permainan Kelereng Pada Siswa Kelas III SD

Untuk Meningkatkan Pemahaman Konsep Perkalian

Maria Fatima $\mathrm{Mei}^{1}$, Stefania Baptis $\mathrm{Seto}^{2}$, Maria Trisna Sero Wondo ${ }^{3}$

Jupika: Jurnal Pendidikan Matematika, Volume 3. Nomor 2. September 2020. Hal.61-70

tugas guru adalah memfasilitasi siswa dalam menemukan sesuatu yang baru (pengetahuan dan keterampilan) melalui pembelajaran secara sendiri bukan apa kata guru. Siswa benar-benar mengalami dan menemukan sendiri apa yang dipelajari sebagai hasil rekonstruksi sendiri. Dengan demikian, siswa akan lebih produktif dan inovatif. Pembelajaran kontekstual akan mendorong ke arah belajar aktif. Belajar aktif adalah suatu sistem belajar mengajar yang menekankan keaktifan siswa secara fisik, mental, intelektual, dan emosional guna memperoleh hasil belajar yang berupa perpaduan antara aspek kognitif, afektif, dan psikomotorik.

Menurut Kadir (2013) Model kontekstual merupakan konsep belajar yang beranggapan bahwa anak akan belajar lebih baik jika lingkungan diciptakan secara ilmiah, artinya belajar akan lebih bermakna jika anak "bekerja" dan "mengalami" sendiri apa yang dipelajarinya, bukan sekedar "mengetahuinya". Pemahaman konsep perkalian dan pembagian dengan menggunakan model pembelajaran CTL dapat dilakukan dengan menggunakan berbagai media diantaranya dengan memanfaatkan benda-benda di sekitar lingkungan siswa seperti batu kerikil, kelereng, biji-bijian, kancing baju, tabel perkalian, kartu angka, manik-manik, sedotan ataupun alat peraga lainnya yang disesuaikan dengan perkembangan mental peserta didik di sekolah (Nurchasanah, 2010). Secara empiris, penelitian Yudiwinata \& Handoyo (2014) menunjukkan bahwa anak-anak yang melakukan permainan tradisional jauh lebih berkembang kemampuan, termasuk kemampuan kerja sama, sportifitas, kemampuan membangun strategi, serta ketangkasan (lari, loncat, keseimbangan) dan karakternya. Ekawati, dkk (2010) menjelaskan bahwa permainan tradisional ternyata mampu berpengaruh dalam mengembangkan kecerdasan intrapersonal anak, Sisi lain meskipun manfaat permainan tradisional sangat banyak bagi tumbuh kembang anak, tidak banyak orangtua yang mengetahui manfaat tersebut, bahkan orangtua sangat jarang masih mengingat bagaimana memainkannya dan jarang menceritakan permainan tradisional yang pernah di mainkan dulu pada anak-anaknya. Hal ini tentu membuat eksistensi permainan tradisional semakin tidak diketahui oleh masyarakat luas.

Prahmana (2012) telah menerapkan pembelajaran menggunakan permainan tradisional untuk siswa kelas III Sekolah Dasar, yang menjadikan siswa lebih antusias belajar dan memahami konsep pembelajaran matematika. Oleh karena itu, peneliti menggunakan Permainan kelereng sebagai "langkah awal" dalam pembelajaran operasi perkalian. Penggunaan kelereng dipilih sebagai media karena materi perkalian yang diberikan dikelas III masih perkalian dasar dan masih sederhana yaitu bilangan cacah dibawah 50 sehingga akan efektif dalam penggunaanya. Kemampuan matematika anak usia SD meliputi kemampuan memahami konsep matematika, kemampuan berhitung dan kemampuan pemecahan masalah. Kemampuan tersebut diperoleh anak setelah mengikuti pembelajaran pada materi bilangan cacah dan operasi hitung, geometri dan pengukuran, dan pengolahan data. Hudojo (2005) menyatakan untuk mengajarkan keterampilan berhitung pada siswa $\mathrm{SD}$, salah satunya dengan metode latihan. Permainan kelereng merupakan suatu permainan untuk 
Pembelajaran Kontekstual Melalui Permainan Kelereng Pada Siswa Kelas III SD

Untuk Meningkatkan Pemahaman Konsep Perkalian

Maria Fatima $\mathrm{Mei}^{1}$, Stefania Baptis $\mathrm{Seto}^{2}$, Maria Trisna Sero Wondo ${ }^{3}$

Jupika: Jurnal Pendidikan Matematika, Volume 3. Nomor 2. September 2020. Hal.61-70

mengajarkan ketrampilan berhitung. Dalam permainan kelereng, setiap pemain meletakkan banyak butir kelereng yang disepakati ke dalam persegi. Anak-anak menyepakati banyak kelerengnya 2 butir, 3 butir, 4 butir, dan 5 butir. Banyak anak yang bermain ada 4 (empat) orang. Semua pemain sudah meletakkan banyak kelereng yang sudah disepakati ke dalam persegi. Satu pemain menghitung banyak kelereng yang ada dalam persegi tersebut. Pemain yang menghitung tersebut bermaksud untuk mengecek banyak kelereng. Caranya menghitung satu persatu kelereng yang ada di dalam persegi dan mengitung banyak pemain dengan kelereng yang diberikan. Banyak kelereng yang disepakati 3 butir jadi 4 × $3=12$, ternyata banyak kelereng yang ada di dalam persegi itu ada 12 butir, sehingga anak yang ditugaskan sebagai penghitung mengatakan jumlahnya pas (tepat banyaknya). Setelah pengecekan tersebut, permainan kelereng dimulai (Siregar \& Lestari, 2018). Kelereng merupakan benda kecil hasil pabrik sebagai alat permainan untuk masyarakat pedesaan yang jauh dari perkotaan, pada beberapa tahun yang lalu. Daerah yang jauh dari perkotaan, fungsi kelereng banyak diganti dengan biji-bijian seperti telah diuraikan terdahulu. Permainan tradisional kelereng adalah permainan kecil yang berbentuk bulat yang terbuat dari kaca. Permainan ini dimainkan oleh anak laki-laki maupun perempuan. Permainan kelereng termasuk salah satu permainan rakyat yang sangat populer. Permainan kelereng disukai banyak anak pada zaman dahulu. Kelereng dibuat dari adonan semen dan kapur dan dibentuk bulat sebesar ibu jari kaki atau terbuat dari batu wali yang dibentuk sedemikian rupa sehingga menyerupai kelereng yang sebenarnya. Permainan ini sangat membutuhkan keahlian. Oleh karena itu peneliti memilih permainan kelereng dengan tujuan untuk mendeskripsikan peningkatan kemampuan pemahaman konsep matematika, keterampilan mengajar guru dalam mengelola pembelajaran matematika dan aktivitas belajar siswa menggunakan model pembelajaran kontekstual melalui permainan kelereng.

\section{METODE}

Jenis Penelitian ini adalah Penelitian Tindakan Kelas (PTK). Arikunto (2014), penelitian tindakan kelas adalah penelitan tindakan (action research) yang dilakukan dengan tujuan memperbaiki mutu praktik pembelajaran di kelasnya. Subjek penelitian siswa kelas III SDI Tetandara dengan jumlah siswa 15 orang terdiri dari 5 siswa laki-laki dan 10 siswa perempuan. Penelitian ini menggunakan model Kemmis dan Mc. Tagart, yaitu model skema dengan menggunakan prosedur yang dipandang sebagai suatu siklus spiral. Siklus ini terdiri dari 4 tahap, yaitu perencanaan, tindakan, observasi, dan refleksi yang kemudian diikuti siklus spiral berikutnya. Penelitian ini dilaksanakan dalam 2 siklus pembelajaran. Tindakan pendahuluan dalam penelitian ini adalah memberikan tes awal untuk mengetahui pemahaman konsep siswa. Kemudian dilaksanakan pembelajaran siklus I menggunakan pembelajaran kontekstual melalui permainan kelereng untuk meningkatkan pemahaman konsep perkalian. Setelah dilaksanakannya pembelajaran, siswa diberi tes siklus I untuk mengetahui pemahaman konsep yang kemudian digunakan sebagai acuan perbaikan untuk 
melaksanakan siklus II. Setelah dilaksanakan siklus II, siswa diberi tes II untuk mengetahui pemahaman konsep yang kemudian akan dijadikan perbandingan antara siklus I dan siklus II. Teknik pengumpulan data dalam penelitian ini yaitu teknik observasi dan tes. Teknik observasi ini bertujuan untuk mengetahui aktivitas guru dan aktivitas siswa selama proses pembelajaran. Teknik tes digunakan untuk mengetahui pemahaman konsep. Instrumen pada penelitian ini menggunakan soal tes berbentuk uraian dan lembar observasi. Butir soal yang dibuat mengacu pada indikator kemampuan pemahaman konsep matematis yang meliputi 1) menyatakan ulang sebuah konsep, 2) memberikan contoh dan bukan contoh dari suatu konsep, 3) menyajikan konsep dalam berbagai bentuk representasi matematis, 4) mengaplikasikan konsep pada pemecahan masalah. Analisis data dalam penelitian ini adalah analisis data kuantitatif dan kualitatif.

\section{HASIL DAN PEMBAHASAN}

Peningkatan aktivitas siswa pada pembelajaran kontekstual melalui permainan kelereng pada siklus I dan siklus II mengalami peningkatan. Berikut ini akan disajikan analisis data berdasarkan observasi tentang aktivitas siswa selama mengikuti pembelajaran yaitu:

\section{Tabel 1. Data Aktivitas Siswa Menggunakan Pembelajaran Kontekstual Melalui Permainan kelereng}

\begin{tabular}{|c|c|c|c|c|c|}
\hline \multirow{2}{*}{ Aspek yang Diamati } & \multicolumn{3}{|c|}{ Persentase } & \multicolumn{2}{c|}{ Peningkatan } \\
\cline { 2 - 6 } & $\begin{array}{c}\text { Pra } \\
\text { Siklus }\end{array}$ & $\begin{array}{c}\text { Siklus } \\
\text { I }\end{array}$ & $\begin{array}{c}\text { Siklus } \\
\text { II }\end{array}$ & & \\
\hline Kesiapan Belajar & 5 & 10 & 12 & 5 & 2 \\
\hline $\begin{array}{c}\text { Memperhatikan } \\
\text { pembelajaran }\end{array}$ & 6 & 10 & 13 & 4 & 3 \\
\hline Mengerjakan Tugas & 7 & 12 & 17 & 5 & 5 \\
\hline Partisipasi & 8 & 12 & 18 & 4 & 6 \\
\hline Bertanya & 9 & 13 & 18 & 4 & 5 \\
\hline Menjawab & 8 & 13 & 18 & 5 & 5 \\
\hline Jumlah & $\mathbf{4 3}$ & $\mathbf{7 0}$ & $\mathbf{9 6}$ & $\mathbf{2 7}$ & $\mathbf{2 6}$ \\
\hline
\end{tabular}

Aktivitas siswa mengalami peningkatan karena siswa sudah mulai memahami perkalian melalui permainan kelereng. Hal ini dapat dilihat dari peningkatan setiap aspek aktivitas siswa dari pra siklus ke siklus I dan dari siklus I ke siklus II. Data peningkatan aktivitas siswa dapat dilihat pada gambar berikut.

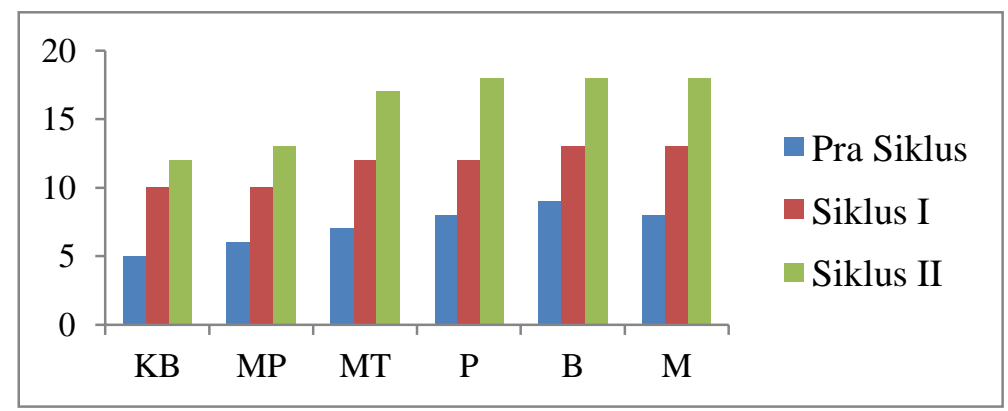

Gambar 1. Data Peningkatan Aktivitas Siswa 
Pembelajaran Kontekstual Melalui Permainan Kelereng Pada Siswa Kelas III SD

Untuk Meningkatkan Pemahaman Konsep Perkalian

Maria Fatima $\mathrm{Mei}^{1}$, Stefania Baptis $\mathrm{Seto}^{2}$, Maria Trisna Sero Wondo

Jupika: Jurnal Pendidikan Matematika, Volume 3. Nomor 2. September 2020. Hal.61-70

Hasil observasi aktivitas Guru menunjukkan adanya peningkatan dari pra siklus, siklus I dan siklus II. Berikut tabel data aktivitas Guru menggunakan pembelajaran kontekstual melalui permainan kelereng.

Tabel 2. Data Aktivitas Guru Menggunakan Pembelajaran Kontekstual Melalui Permainan kelereng

\begin{tabular}{|c|c|c|c|c|c|}
\hline Uraian & $\begin{array}{c}\text { Pra } \\
\text { Siklus }\end{array}$ & $\begin{array}{c}\text { Siklus } \\
\text { I }\end{array}$ & $\begin{array}{c}\text { Siklus } \\
\text { II }\end{array}$ & \multicolumn{2}{|c|}{$\begin{array}{c}\text { Peningkatan } \\
\text { Tiap Siklus }\end{array}$} \\
\hline Keberhasilan & $54,5 \%$ & $70,25 \%$ & $87,7 \%$ & $15,75 \%$ & $17,45 \%$ \\
\hline
\end{tabular}

Aktivitas Guru mengalami peningkatan dari pra siklus ke siklus I sebesar $15,75 \%$ dan dari siklus I ke siklus II sebesar 17,45\%. Data peningkatan aktivitas guru dapat dilihat pada gambar berikut.

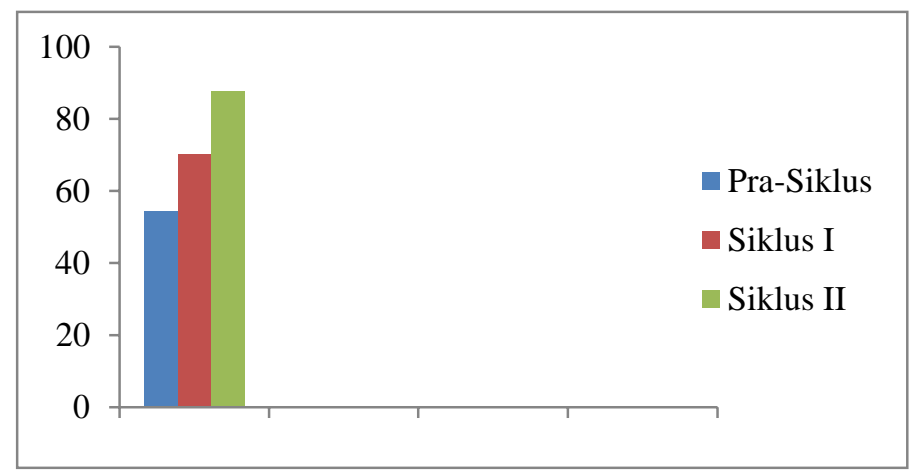

\section{Gambar 2. Data Peningkatan Aktivitas Guru}

Sebelum siklus I, diberikan tes awal pemahaman konsep diperoleh nilai rata-rata 48,40. Pada tes pemahaman konsep siklus I, diperoleh data bahwa semua siswa kelas III SDI Tetandara mengikuti tes pemahaman konsep yaitu sebanyak 15 siswa. Dari jumlah tersebut diperoleh rata-rata kelas 68,86 dengan 9 siswa yang mencapai ketuntasan dan 6 siswa tidak mencapai ketuntasan. Hal ini menunjukkan adanya peningkatan sebelum diberikan perlakuan dan sesudah diberikan perlakuan. Pada hasil tersebut, ketuntasan siswa masih belum seperti yang diharapkan karena belum mencapai kriteria ketuntasan, maka dilakukan siklus ke II untuk memperbaiki siklus sebelumnya. Pada tes pemahaman konsep siklus II diperoleh rata-rata 82 dengan 13 siswa yang mencapai ketuntasan dan 2 orang siswa belum mencapai ketuntasan. Dari hasil tes pemahaman konsep siklus I ke siklus II mengalami peningkatan sesuai dengan kriteria ketuntasan yaitu sangat baik. Hasil tes pemahaman konsep siswa dapat dilihat pada tabel berikut.

Tabel 3. Data Pemahaman Konsep Siswa

\begin{tabular}{|c|l|r|c|c|c|c|}
\hline No & $\begin{array}{c}\text { Indikator Pemahaman } \\
\text { Konsep Siswa }\end{array}$ & $\begin{array}{c}\text { Pra } \\
\text { Siklus }\end{array}$ & Siklus I & \multicolumn{2}{|c|}{ Siklus II } & \multicolumn{2}{|c|}{ Peningkatan } \\
\hline 1 & $\begin{array}{l}\text { Menyatakan ulang sebuah } \\
\text { konsep }\end{array}$ & $\begin{array}{r}7 \text { Siswa } \\
(46.67 \%)\end{array}$ & $\begin{array}{c}11 \text { Siswa } \\
(73.33 \%)\end{array}$ & $\begin{array}{c}15 \text { Siswa } \\
(100 \%)\end{array}$ & $26,66 \%$ & $26,67 \%$ \\
\hline
\end{tabular}


Pembelajaran Kontekstual Melalui Permainan Kelereng Pada Siswa Kelas III SD

Untuk Meningkatkan Pemahaman Konsep Perkalian

Maria Fatima $\mathrm{Mei}^{1}$, Stefania Baptis $\mathrm{Seto}^{2}$, Maria Trisna Sero Wondo ${ }^{3}$

Jupika: Jurnal Pendidikan Matematika, Volume 3. Nomor 2. September 2020. Hal.61-70

\begin{tabular}{|c|l|c|c|c|c|c|}
\hline No & \multicolumn{1}{|c|}{$\begin{array}{c}\text { Indikator Pemahaman } \\
\text { Konsep Siswa }\end{array}$} & $\begin{array}{c}\text { Pra } \\
\text { Siklus }\end{array}$ & Siklus I & \multicolumn{2}{|c|}{ Siklus II } & \multicolumn{2}{|c|}{ Peningkatan } \\
\hline 2 & $\begin{array}{l}\text { Memberi contoh dan bukan } \\
\text { contoh dari suatu konsep }\end{array}$ & $\begin{array}{r}7 \text { siswa } \\
(46.67 \%)\end{array}$ & $\begin{array}{c}10 \text { Siswa } \\
(66.67 \%)\end{array}$ & $\begin{array}{c}14 \text { Siswa } \\
(93.33 \%)\end{array}$ & $20 \%$ & $26,66 \%$ \\
\hline 3 & $\begin{array}{l}\text { Menyajikan konsep dalam } \\
\text { berbagai bentuk representasi } \\
\text { matematis }\end{array}$ & 8 Siswa & 9 Siswa & 14 Siswa & & $23 \%$ \\
\hline 4 & $\begin{array}{l}\text { Mengaplikasikan konsep } \\
\text { pada pemecahan masalah }\end{array}$ & $\begin{array}{c}5 \text { Siswa } \\
(33.33 \%)\end{array}$ & $\begin{array}{c}10 \text { Siswa } \\
(66.67 \%)\end{array}$ & $\begin{array}{c}14 \text { Siswa } \\
(93.33 \%)\end{array}$ & $33,34 \%$ & $26,66 \%$ \\
\hline
\end{tabular}

Data Peningkatan Pemahaman konsep matematika siswa dapat juga dilihat pada gambar berikut.

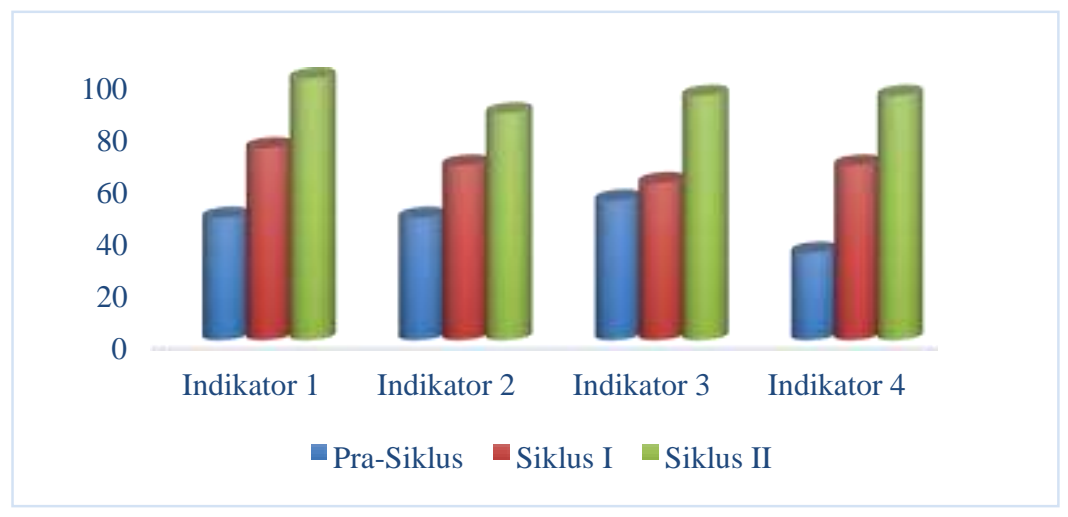

Gambar 3. Data Peningkatan Pemahaman Konsep Siswa

\section{KESIMPULAN}

Berdasarkan penelitian tindakan kelas yang telah dilakukan dapat disimpulkan penggunaan model pembelajaran kontekstual dapat meningkatkan aktivitas guru, aktivitas siswa dan pemahaman konsep perkalian siswa. Peningkatan tersebut dapat dilihat dari hasil penelitian sebagai berikut. (1) peningkatan aktivitas guru dari pra siklus ke siklus I sebesar 15,75\%, siklus I ke siklus II sebesar 17,45\%. (2) Aktivitas siswa mengalami peningkatan dari pra siklus ke siklus I sebesar $27 \%$, dan siklus I ke siklus II sebesar 26\%. (3) Peningkatan pemahaman konsep perkalian siswa pada pra siklus ke siklus I sebesar 26,66\% untuk indikator 1, 20\% untuk indikator 2, 6,67\% untuk indikator 3, dan $33,34 \%$ untuk indikator 4. Sedangkan untuk siklus I ke siklus II mengalami peningkatan sebesar 26,67\% untuk indikator 1, 26,66\% untuk indikator 2, 33,33\% untuk indikator 3, dan 26,66\% untuk indikator 4. 
Pembelajaran Kontekstual Melalui Permainan Kelereng Pada Siswa Kelas III SD

Untuk Meningkatkan Pemahaman Konsep Perkalian

Maria Fatima $\mathrm{Mei}^{1}$, Stefania Baptis $\mathrm{Seto}^{2}$, Maria Trisna Sero Wondo ${ }^{3}$

Jupika: Jurnal Pendidikan Matematika, Volume 3. Nomor 2. September 2020. Hal.61-70

\section{DAFTAR PUSTAKA}

Arikunto, S. (2014). Prosedur Penelitian Suatu Pendekatan Praktik. Rineka Cipta.

Depdiknas. (2003). Pedoman Khusus Pengembangan Sistem Penilaian Berbasis Kompetensi SMP. Jakarta: Depdiknas.

Djamarah, S.B. (2000). Guru dan Anak Didik dalam Interaksi Edukatif. Jakarta: Rineka Cipta.

Duffin, J.M.\& Simpson, A.P. 2000. A Search for understanding. Journal of Mathematical Behavior. $18(4)$.

Ekawati, Y. N., Saputra, N. E., Rozalina., Restya, W. P. D., Nurlita, I., (2010). Pengaruh bermain melalui permainan tradisional terhadap kecerdasan intrapersonal anak. Jurnal Ilmiah Mhasiswa berprestasi Vol. 1 No. 2. Universitas Ahmad Dahlan.

Febriani, P., Widada, W., \& Herawaty, D. (2019). Pengaruh Pembelajaran Matematika Realistik Berbasis Etnomatematika Terhadap Kemampuan Pemahaman Konsep Matematika Siswa SMA Kota Bengkulu. Jurnal Pendidikan Matematika Raflesia, 04(02), 120-135.

Hudojo, H. (2005). Pengembangan Kurikulum dan Pembelajaran Matematika. Malang: UM Press.

Jhonson, E. B. P. (2007). Contextual Teaching and Learning. Mizan Learning Center (MCL).

Jumadi. (2004). Pembelajaran Kontekstual dan Implementasinya. Workshop Sosialisasi Dan Implementasi Kurikulum 2004, 113(2), 180-190.

Kadir, A. (2013). Konsep Pembelajaran Kontekstual Di Sekolah. Dinamika Ilmu, 13(1), 17-38. http://journal.iain-samarinda.ac.id/index.php/dinamika_ilmu/article/view/20.

Kunandar. (2009). Guru Profesional Implementasi Kurikulum Tingkat Satuan Pendidikan (KTSP) dan Sukses dalam Sertifikasi Guru. Jakarta: PT Raja Grafindo Persada.

Mei, A., Naja, F. Y., \& Sa'o, S. (2020). Pembelajaran Matematika Realistik Berbasis Kontekstual Untuk Materi Geometri Pada Siswa Kelas VII SMPN 2 Ende Selatan. EduMatSains, 5(1), 1928.

Mei, M. F. (2016). Pembelajaran Matematika Dengan Model Siklus Belajar (Learning Cycle) $5 e$ Pada Materi Refleksi Dan Translasi Untuk Meningkatkan Hasil Belajar Siswa Kelas VII SMP. Universitas Negeri Surabaya.

NCTM. (2000). Principles and Standards for School Mathematics. United states of America: The Nasional Council of Teachers of Mathematics, Inc.

Nila, K. (2008). Pemahaman konsep matematik dalam pembelajaran matematika. Prosiding SeminarNasional Matematika Dan Pendidikan Matematika, Jurusan Pendidikan Matematika Fakultas Matematika Dan Ilmu Pengetahuan Alam Universitas Negeri Yogyakarta, 229-235.

Nurchasanah, F. (2010). Peningkatan Kemampuan Menghitung Perkalian dan Pembagian Melalui Model Pembelajaran Kontekstual Pada Siswa Kelas II Sekolah Dasar Negeri Gendingan 5 Widodaren Ngawi tahun Pelajaran 2009/2010. Universitas Sebelas Maret Surakarta.

Prahmana, R.C.I., Zulkardi., Hartono, Y. (2012). Learning Multiplication Using Indonesian Traditional Game in Third Grade. Journal on Mathematics Education (IndoMS-JME), 3(2), 
Pembelajaran Kontekstual Melalui Permainan Kelereng Pada Siswa Kelas III SD

Untuk Meningkatkan Pemahaman Konsep Perkalian

Maria Fatima $\mathrm{Mei}^{1}$, Stefania Baptis Seto ${ }^{2}$, Maria Trisna Sero Wondo ${ }^{3}$

Jupika: Jurnal Pendidikan Matematika, Volume 3. Nomor 2. September 2020. Hal.61-70

\section{$115-132$.}

Rahayu. (2018). Analisis Kemempuan Pemahaman Matematik Siswa Mts di Kabupaten Bandung Barat. Jurnal Math Educator Nusantara (JMEN, 4(1).

Siregar, N., Lestari W. (2018). Peranan Permainan Tradisional Dalam Mengembangkan Kemampuan Matematika Anak Usia Sekolah Dasar. Jurnal Mercumatika : Jurnal Penelitian Matematika dan Pendidikan Matematika. Vol. 2 No 2, April 2018, pp. 1-7 ISSN: 2548-1819.

Wardhani, Sri. 2008. Analisis SI dan SKL Mata Pelajaran Matematika SMP/MTs untuk Optimalisasi Tujuan Mata Pelajaran Matematika. Yogyakarta: Pusat Pengembangan dan Pemberdayaan Pendidik dan Tenaga Kependidikan Matematika.

Yudiwinata, H. P., Handoyo, P. (2014). Permainan tradisional dalam budaya dan perkembangan anak. Jurnal Paradigma. Vol. 02 Nomor 3. Universitas Negeri Surabaya 